\title{
Peningkatan Pengetahuan Masyarakat melalui Pelatihan Pengolahan Jahe Merah menjadi Chew Gummy di Desa Senggigi
}

\section{(Increasing Public Knowledge through Training on Processing Red Ginger into Chew Gummy in Senggigi Village)}

\author{
Wahida Hajrin*, Yohanes Juliantoni, Windah Anugerah Subaidah \\ Program Studi Farmasi, Fakultas Kedokteran, Universitas Mataram, Jalan Majapahit No. 62 Mataram, \\ Nusa Tenggara Barat 83125. \\ *Penulis Korespondensi: wahida08farm@gmail.com \\ Diterima Januari 2020/Disetujui Januari 2021
}

\begin{abstract}
ABSTRAK
Jahe merah merupakan rimpang yang digunakan untuk mengobati sakit tenggorokan, batuk kering, kolik, rematik, sakit kepala, dan perut kembung. Kegiatan pengabdian masyarakat ini bertujuan untuk memberikan pengetahuan pada masyarakat tentang manfaat jahe merah bagi kesehatan, serta memberikan pengetahuan tentang salah satu cara pengolahan produk jahe merah yang layak jual. Materi tentang manfaat jahe merah bagi kesehatan disampaikan dengan presentasi langsung dan pengolahan jahe merah menjadi chew gummy didemokan secara langsung di depan peserta. Kegiatan dilakukan di Kantor Desa Senggigi dengan melibatkan kader posyandu dan ibu-ibu PKK Desa Senggigi sebagai peserta. Peserta diberikan pre-test dan post-test untuk mengetahui peningkatan pemahaman peserta. Hasil menunjukkan adanya peningkatan nilai post-test dari nilai pre-test tentang manfaat jahe merah dan pengolahannya. Peserta memahami manfaat jahe merah bagi kesehatan dan dapat mengolah jahe merah menjadi sediaan chew gummy.
\end{abstract}

Kata kunci: chew gummy, jahe merah, pelatihan, TOGA

\section{ABSTRACT}

Red ginger is a beneficial rhizome used to treat sore throats, dry cough, colic, rheumatism, headache, and flatulence. This community service aims to provide knowledge about the benefits of red ginger for health and how to process red ginger to a worth to sell products. The knowledge about the benefits of red ginger for health presented directly and the processing of chew gummy demonstrated in front of the participants. The community service was carried out at the Senggigi Village Office by involving by involving cadre of Posyandu and PKK asparticipants. The participants are given a pre-test and post-test to determine the increase in participant understanding. The results showed an increase in post-test scores from pre-test values about the benefits of red ginger and its processing. Participants understand the benefits of red ginger for health and can process red ginger into chew gummy preparations.

Keywords: chew gummy, red ginger, TOGA, training

\section{PENDAHULUAN}

Rimpang jahe merah merupakan salah satu tanaman obat yang memiliki berbagai khasiat, salah satunya adalah sebagai antimual (Meltzer 2000; Vutyavanich et al. 2001; Basirat et al. 2009). Jahe merah sudah banyak digunakan dalam industri obat tradisional dan merupakan salah satu komoditi ekspor bernilai tinggi. Budi daya jahe merah dalam jumlah besar telah banyak dilakukan di berbagai daerah di Indonesia untuk memenuhi kebutuhan jahe merah di dalam dan luar negeri (Waridin 2007; Sambodo et al. 2017). Pengolahan jahe merah menjadi suatu produk siap konsumsi sudah banyak dilakukan.
Pengolahan yang paling sederhana adalah pengolahan menjadi serbuk jahe, namun serbuk jahe merah memiliki kelarutan yang rendah saat diseduh dengan air (Daulay 2017). Pengembangan untuk meningkatkan kelarutan dilakukan dengan pembentukan serbuk melalui prosses spray drying (Iswati et al. 2017), namun kelemahannya adalah pengolahan ini membutuhkan alat khusus dan mahal. Inovasi lain yang dilakukan dalam pengolahan jahe merah adalah dengan membuat pie susu jahe merah (Fauzan et al. 2020).

Desa Senggigi merupakan salah satu desa di Kecamatan Batu Layar Kabupaten Lombok Barat. Pada tahun 2018, Desa Senggigi memiliki 
penduduk sebanyak 6.205 jiwa, terdiri atas 3.305 jiwa laki-laki dan 2.900 jiwa perempuan, terbagi dalam $1.865 \mathrm{KK}$. Jumlah penduduk yang tinggi tersebar pada 4 dusun, yaitu Dusun Senggigi, Loco, Kerandangan, dan Mangsit. Keempat dusun tersebar di bibir pantai sepanjang $3 \mathrm{~km}$. Luas wilayah desa Senggigi \pm 1.703 ha. Pembagian wilayah menurut penggunaannya adalah 578 ha pekarangan, 254 ha perkebunan, 569 ha pemukiman, dan 0,6 ha lain-lain.

Masyarakat Kerandangan Desa Senggigi telah banyak mengembangkan Taman Obat Keluarga (Toga), namun sekarang masih dalam tahap pengembangan ulang karena terjadi kerusakan saat gempa bumi. Salah satu tanaman yang sudah banyak dikembangkan dan memiliki nilai jual adalah rimpang jahe merah. Rimpang jahe merah hasil Toga dijual dalam bentuk segar oleh masyarakat. Jumlah rimpang jahe merah yang dihasilkan oleh masyarakat pada umumnya tidak seperti hasil budi daya pada lahan luas untuk tujuan supply ke industri maupun ekspor, sehingga nilai jual yang dihasilkan tidak dapat meningkatkan taraf hidup masyarakat secara signifikan.

Salah satu cara yang dapat dilakukan untuk meningkatkan nilai jual jahe merah yang dihasilkan oleh masyarakat adalah dengan mengolahnya menjadi suatu produk yang dapat dijual. Pengolahan jahe merah dengan cara yang tepat akan berpengaruh pada kualitas dan aseptabilitas produk yang dihasilkan. Salah satu sediaan yang aseptabel bagi konsumen adalah chew gummy. Chew gummy atau sering disebut gummy candies merupakan bentuk produk kenyal dan manis yang terbuat dari gelatin atau karagenan, yang ditambahkan pemanis (Achumi et al. 2018). Sediaan ini memiliki beberapa kelebihan, yaitu praktis dalam penggunaan, mudah dalam menyajikan, memiliki rasa yang enak, dan bentuk yang mudah untuk divariasi, sehingga lebih disukai oleh orang dewasa maupun anakanak (Jadhav \& Mohite 2014). Berbagai bahan obat maupun nutrasetikal telah banyak dikembangkan sebagai sediaan chew gummy, antara lain parasetamol (Chabib et al. 2014), buah Markisa Kuning (Firdaus et al. 2013), sari buah Duwet (Juliantoni et al. 2018), dan chew gummy jus nanas dan jus wortel (Achumi et al. 2018). Tujuan dari pengabdian kepada masyarakat ini adalah memberikan pengetahuan kepada masyarakat tentang manfaat jahe merah bagi kesehatan dan cara mengolah rimpang jahe merah menjadi sediaan chew gummy.

\section{METODE PELAKSANAAN KEGIATAN}

\section{Tempat dan Waktu Kegiatan}

Kegiatan sosialisasi dan pelatihan dilakukan di balai Desa Senggigi, bertempat di Dusun Kerandangan, Desa Senggigi, Kecamatan Batulayar, Nusa Tenggara Barat. Proses pelaksanaan sosialisasi dan pelatihan mulai dari tahap persiapan hingga evaluasi adalah bulan JuliAgustus 2019. Mitra yang terlibat pada kegiatan ini adalah anggota PKK dan kader posyandu Desa Senggigi.

\section{Alat dan Bahan}

Alat yang digunakan dalam pelatihan ini adalah kompor, panci, sutil, cetakan chew gummy, saringan, baskom, sound system, dan LCD proyektor. Bahan yang digunakan dalam pelatihan ini adalah jahe merah, gula pasir, gelatin, asam sitrat, pewarna makanan, dan air.

\section{Tahapan Pelaksanaan Kegiatan \\ - Tahap persiapan}

Pada tahap persiapan dilakukan koordinasi dengan pemerintah desa setempat untuk mengomunikasikan segala hal terkait kegiatan. Halhal penting yang disampaikan adalah tujuan kegiatan, sasaran, bentuk kegiatan, dan luaran yang diharapkan. Tahap persiapan ini dimanfaatkan juga untuk meminta dukungan berupa izin dari pemerintah setempat terhadap acara yang akan diselenggarakan. Selain itu, pada tahap persiapan juga dikoordinasikan waktu dan tempat kegiatan. Koordinasi dilakukan dengan ketua PKK dan ketua Kader Posyandu Desa Senggigi. Persiapan alat dan bahan untuk pelatihan juga dilakukan demi kelancaran kegiatan di lokasi.

\section{- Tahap pelaksanaan}

Kegiatan sosialisasi dan pelatihan pembuatan chew gummy jahe merah dilakukan pada tanggal 29 Agustus 2019. Kegiatan ini meliputi penyampaian sosialisasi kepada ibu-ibu PKK Desa Senggigi dan dilanjutkan dengan pelatihan pembuatan chew gummy jahe merah. Metode yang digunakan adalah penyampaian materi secara langsung melalui presentasi dan pemberian leaflet, dilanjutkan dengan demo pembuatan chew gummy jahe merah. Sebelum melakukan sosialisasi, peserta diberikan pre-test untuk mengetahui tingkat pengetahuan peserta tentang jahe merah dan pembuatan chew gummy. Materi sosialisasi yang disampaikan meliputi macam-macam jahe, khasiat jahe merah bagi 
kesehatan, cara pengolahan rimpang jahe merah pascapanen, serta pengolahan jahe merah menjadi sediaan chew gummy. Setelah pemberian materi, peserta diberikan pelatihan melalui demo cara pembuatan sediaan chew gummy. Peserta diminta ikut serta dalam proses pembuatan sediaan chew gummy. Akhir sesi, dibuka sesi tanya jawab dan ditutup dengan post-test.

\section{- Tahap evaluasi}

Proses evaluasi yang dilakukan adalah dengan memberikan pre-test dan post-test bagi peserta sebelum dan sesudah sosialisasi dan pelatihan. Sebelum memulai kegiatan, peserta yang telah mengisi daftar hadir diminta mengisi kuisioner sebagai data pre-test. Setelah sosialisasi dan pelatihan selesai, peserta kembali diberikan kuisioner dengan pertanyaan yang sama dengan kuisioner awal (pre-test). Data ini digunakan sebagai data post-test. Pre-test dan post-test yang diberikan adalah pertanyaan terkait materi dan pelatihan pengolahan jahe merah menjadi chew gummy sebanyak 8 buah soal pilihan ganda.

Kuisioner pre-test yang telah diisi oleh peserta dinilai dengan ketentuan jawaban benar diberi skor 1 (satu) dan jawaban salah diberi skor 0 (nol) untuk masing-masing soal. Skor total 18 peserta dijumlahkan kemudian ditentukan persentase tingkat pemahaman menggunakan rumus berikut:

$$
\% \text { Pemahaman }=\frac{\text { Skor total seluruh peserta }}{\text { Skor maksimum }} \times 100 \%
$$

Skor maksimum adalah skor yang diperoleh jika semua peserta menjawab semua pertanyaan dengan benar, sehingga diperoleh tingkat pemahaman $100 \%$. Pengolahan data post-test dilakukan dengan cara yang sama dengan pengolahan data pre-test.

Tingkat pemahaman peserta sebelum dan sesudah kegiatan ditentukan dengan membandingkan nilai persentase pemahaman pre-test dan post-test. Nilai persentase tingkat pemahaman pre-test dan post-test dianalisis dengan uji normalitas menggunakan uji Saphiro-Wilk, uji homogenitas dengan Levene test, dan dilanjutkan dengan uji Kruskal Wallis.

\section{HASIL DAN PEMBAHASAN}

\section{Dukungan Pemerintah Desa Senggigi}

Pemerintah Desa Senggigi sangat mendukung program kegiatan yang dilakukan. Dukungan yang diberikan pemerintah desa berupa kemudahan dalam koordinasi teknis pelaksanaan kegiatan, penyediaan tempat kegiatan yang layak, serta penyediaan fasilitas lain yang dibutuhkan selama kegiatan berlangsung. Pada dasarnya, pemerintah Desa Senggigi sangat terbuka menerima sosialisasi maupun pelatihan yang bermanfaat bagi ibu-ibu PKK dan kader posyandu pada khususnya, dan masyarakat Desa Senggigi pada umumnya. Pemerintah mendukung dengan penuh kegiatan sosialisasi dan pelatihan terutama yang dapat membangun ekonomi dan kesehatan masyarakat dalam rangka memulihkan kondisi pascagempa di Desa Senggigi.

\section{Pelaksanaan Sosialisasi}

Pelaksanaan kegiatan sosialisasi diawali dengan acara pembukaan yang dilakukan oleh Kepala Desa Senggigi. Peserta sosialisasi sebanyak 18 orang terdiri atas 15 wanita dan 3 laki-laki, merupakan anggota PKK dan kader posyandu Desa Senggigi. Penyampaian materi sosialisasi dilakukan secara komunikatif, dengan lisan maupun tulisan, yaitu melalui power point presentasi dan leaflet. Hal ini dilakukan untuk memudahkan peserta sosialisasi dalam memahami materi yang disampaikan.

Materi yang disampaikan dalam sosialisasi adalah manfaat jahe merah bagi kesehatan dan cara pembuatan chew gummy. Pada materi tentang manfaat jahe merah bagi kesehatan, peserta diberikan pemaparan tentang jenis-jenis jahe, penggunaan jahe, khasiat jahe merah, nilai ekonomi jahe merah, serta peluang usaha melalui penanaman jahe merah sebagai Toga. Materi ini perlu disampaikan untuk meningkatkan pengetahuan masyarakat tentang manfaat jahe merah. Selain itu, masyarakat perlu dipacu untuk mengembangkan jahe merah menjadi salah satu tanaman obat keluarga (Toga). Pada materi pembuatan chew gummy jahe merah dipaparkan tentang kelebihan sediaan chew gummy, bahanbahan dan fungsi masing-masing bahan yang digunakan dalam pembuatan chew gummy jahe merah, serta cara pembuatan sediaan chew gummy jahe merah.

Pada akhir sesi, dibuka sesi tanya jawab untuk meningkatkan pemahaman dan pengetahuan peserta. Peserta sosialisasi sangat antusias mengikuti kegiatan sosialisasi, dilihat dari banyaknya pertanyaan yang disampaikan. Kegiatan sosialisasi dapat dilihat pada Gambar 1.

\section{Pelaksanaan Pelatihan Pembuatan Chew Gummy}

Pelatihan pembuatan chew gummy jahe merah bagi seluruh peserta sosialisasi dilakukan melalui 
demo. Demo yang dilakukan disaksikan oleh seluruh peserta dengan melibatkan langsung dua orang peserta agar peserta dapat benar-benar memahami cara pembuatan chew gummy jahe merah. Pembuatan chew gummy diawali dengan pembuatan sari jahe merah. Sebanyak 0,5 kg jahe merah yang telah dikupas, ditambahkan $700 \mathrm{~mL}$ air, kemudian diblender. Jahe merah yang telah halus dimasak hingga mendidih dan disaring. Sebanyak 200 g sari jahe merah dicampurkan dengan 200 g gula pasir, dan 150 g gelatin yang telah dilarutkan dalam $250 \mathrm{~mL}$ air hangat. Campuran dimasak hingga mendidih, kemudian ditambahkan pewarna makanan dan asam sitrat. Campuran dituang pada cetakan dan dibiarkan hingga dingin. Chew gummy jahe merah yang diperoleh memiliki aroma khas jahe, rasa manis dan agak pedas, serta bertekstur kenyal. Peserta sangat antusias dibuktikan dengan semangatnya dalam mengikuti pelatihan. Proses pelatihan pembuatan chew gummy jahe merah, keikutsertaan peserta, dan hasil chew gummy jahe merah dapat dilihat pada Gambar 2, 3, dan 4.

\section{Analisis Hasil Kegiatan}

Hasil pre-test dan post-test disajikan dalam Tabel 1. Berdasarkan hasil pre-test dan post-test, persentase pemahaman untuk 18 peserta dengan 8 buah soal adalah 40,97\% untuk pre-test dan mengalami peningkatan pada post-test yaitu sebesar 76,39\%. Analisis statistik dilakukan untuk mengetahui ada tidaknya perbedaan yang signifikan antara hasil pre-test dan post-test. Uji Saphiro-Wilk menunjukkan data terdistribusi normal ( $p$-value $=0,108)$ dan uji Levene test menunjukkan data tidak homogen ( $p$-value $=0,033)$, sehingga uji dilanjutkan dengan uji Kruskal Wallis. Hasil uji menunjukkan bahwa terdapat perbedaan yang signifikan antara nilai pre-test dan post-test ( $p$-value $=0,002)$, sehingga dapat disimpulkan bahwa sosialisasi dan pelatihan ini meningkatkan pemahaman peserta tentang manfaat jahe merah bagi kesehatan dan cara pembuatan chew gummy jahe merah.

Salah satu aspek penting yang perlu diperhatikan dalam memberikan pelatihan adalah penggunaan metode pelatihan. Metode pelatihan yang tepat akan memberikan hasil yang baik bagi peserta. Metode yang digunakan dalam pelatihan pembuatan chew gummy jahe merah sudah tepat, terbukti dengan adanya peningkatan hasil evaluasi setelah kegiatan pelatihan selesai. Evaluasi dilakukan untuk mengetahui tingkat keberhasilan program yang dilakukan, tidak hanya

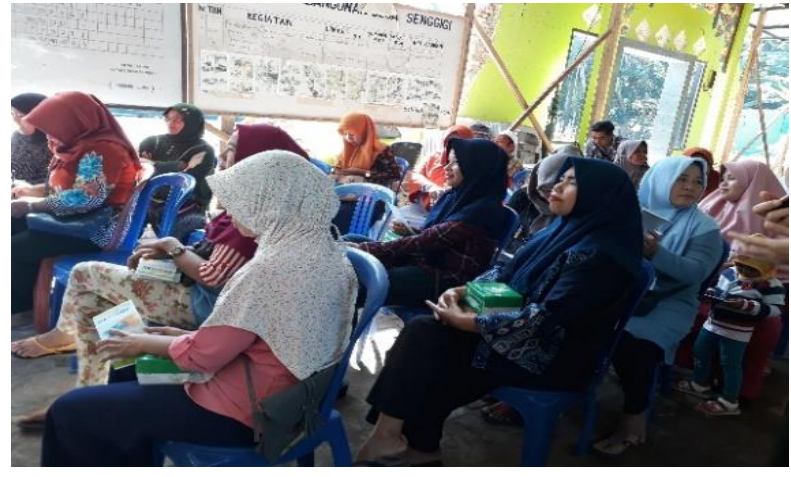

Gambar 1 Kegiatan sosialisasi manfaat jahe merah bagi kesehatan.

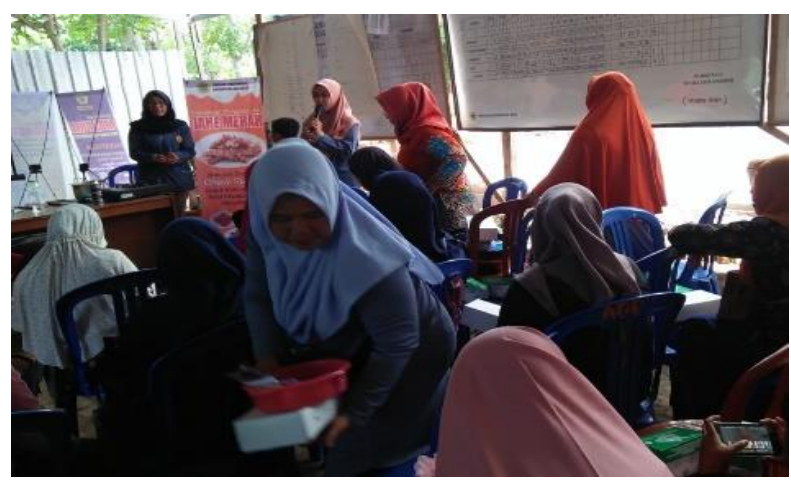

Gambar 2 Pelatihan pembuatan chew gummy jahe merah.

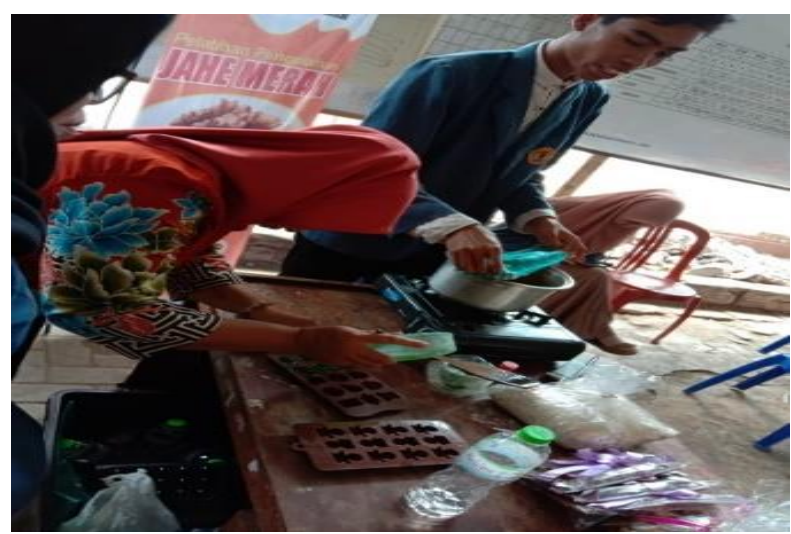

Gambar 3 Peserta ikut terlibat dalam pembuatan chew gummy jahe merah.

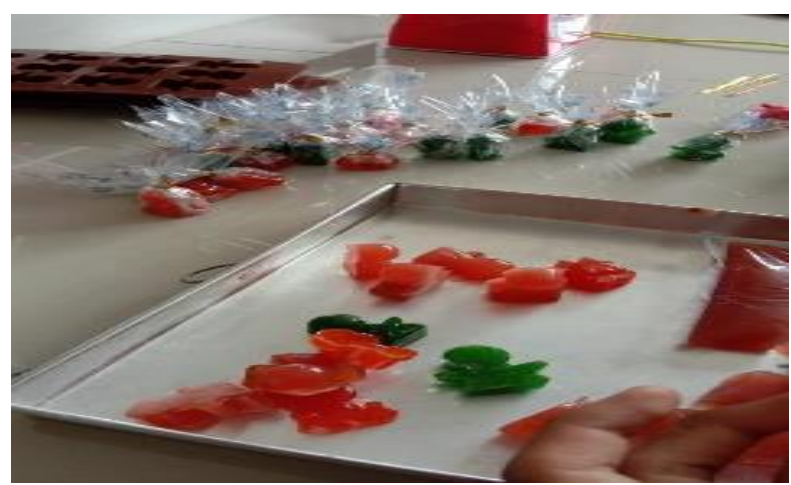

Gambar 4 Hasil produk chew gummy jahe merah. 
Tabel 1 Data skor pre-test dan post-test

\begin{tabular}{ccc}
\hline \multirow{2}{*}{ Peserta } & \multicolumn{2}{c}{ Jumlah skor } \\
\cline { 2 - 3 } & Pre-test & Post-test \\
\hline 1 & 3 & 7 \\
2 & 4 & 6 \\
3 & 4 & 7 \\
4 & 4 & 8 \\
5 & 1 & 8 \\
6 & 3 & 7 \\
7 & 1 & 4 \\
8 & 2 & 7 \\
9 & 5 & 3 \\
10 & 4 & 6 \\
11 & 2 & 6 \\
12 & 4 & 7 \\
13 & 2 & 6 \\
14 & 6 & 6 \\
15 & 2 & 6 \\
16 & 4 & 5 \\
17 & 2 & 5 \\
18 & 6 & 6 \\
\hline Skor total & 59 & 110 \\
\hline
\end{tabular}

sebatas pengujian kemampuan peserta sebelum dan sesudah kegiatan (Kurniadi 2007).

Pada kegiatan ini, terdapat beberapa kendala yang dihadapi baik dari tahap persiapan hingga pelaksanaan kegiatan. Waktu pelaksanaan kegiatan sulit ditentukan karena berbenturan dengan jadwal kegiatan lain di balai Desa Senggigi. Koordinasi penentuan waktu pelaksanaan membutuhkan waktu lama karena perlu kesesuaian waktu antara pelaksana dan peserta kegiatan. Selain itu, tempat pelaksanaan kegiatan hanya mampu menampung jumlah peserta yang terbatas, hal ini karena balai desa masih dalam kondisi perbaikan pascagempa. Keterbatasan peralatan dalam pelatihan menyebabkan hanya sedikit peserta yang dapat terlibat langsung dalam pembuatan chew gummy. Pelaksanaan kegiatan yang terlalu singkat juga menjadi kendala dalam kegiatan ini, hal ini karena pada pagi hingga siang hari terdapat berbagai kesibukan ibu rumah tangga bagi ibu-ibu PKK maupun kader posyandu.

\section{Manfaat dan Dampak Pelatihan}

Pelatihan merupakan suatu bentuk pembelajaran bagi suatu komunitas organisasi dengan mensyaratkan adanya pemenuhan skills, knowledge, dan ability. Program pelatihan memiliki dampak yang positif baik bagi individu maupun organisasi. Skill yang diperoleh melalui pelatihan akan meningkatkan kapabilitas individu karena adanya peningkatan keterampilan atau keahlian (Kurniadi 2007). Dampak positif bagi peserta pelatihan adalah pengetahuan tentang manfaat jahe merah bagi kesehatan dan cara pengolahan jahe merah menjadi sediaan chew gummy, sehingga dapat meningkatkan minat peserta dalam menata kembali penanaman jahe merah di Desa Senggigi. Kegiatan ini diharapkan dapat berkelanjutan untuk benarbenar memberikan manfaat bagi masyarakat. Masyarakat membutuhkan pengetahuan yang lebih banyak dan menyeluruh terkait pengembangan tanaman jahe merah, pengolahan yang tepat, dan proses pemasaran hingga dapat memiliki dampak langsung terhadap perekonomian masyarakat. Sebagai contoh, jenis rimpang dan komposisi media tanam jahe merah sangat berpengaruh terhadap kualitas jahe merah yang dihasilkan (Aidin et al. 2016). Waktu panen yang juga berpengaruh terhadap kualitas jahe merah, misalnya jahe merah yang digunakan untuk pengobatan dapat dipanen pada minggu ke 10 hingga 12 (Triyono \& Sumarmi 2018). Teknik atau strategi pemasaran yang tepat juga perlu dibekali bagi masyarakat, misalnya penerapan $4 \mathrm{P}$ (Product, Price, Place, Promotion) dan STP (Segmentation, Targeting, Positioning) yang merupakan hal penting untuk meningkatkan penjualan (Hartono et al. 2012). Sehingga, sebagai bentuk keberlanjutan dari pelatihan ini, perlu dilakukan pelatihan lanjutan terkait dengan cara penanaman jahe merah yang tepat, cara pengolahan pascapanen, cara pengolahan, hingga teknik pemasaran yang tepat.

\section{SIMPULAN}

Pemahaman ibu-ibu PKK dan kader Posyandu desa Senggigi terhadap manfaat jahe merah bagi kesehatan dan cara membuat chew gummy jahe merah meningkat dari 40,97\% menjadi $76,39 \%$ setelah dilakukan kegiatan sosialisasi dan pelatihan. Keterbatasan waktu dan peralatan dalam pelatihan menyebabkan kurang efektifnya kegiatan yang dilakukan sehingga perlu adanya keberlanjutan program pelatihan ini. Pendampingan perlu dilakukan bagi masyarakat dalam pengembangan jahe merah secara menyeluruh mulai dari cara penanaman hingga teknik pemasaran yang tepat agar dapat berdampak langsung terhadap perekonomian masyarakat.

\section{DAFTAR PUSTAKA}

Achumi LV, Peter ERS, Das A. 2018. Studies on preparation of gummy candy using pineapple 
juice and carrot juice. International Journal of Chemical Studies. 6(5): 1015-1018.

Aidin A, Sahiri N, Madauna I. 2016. Pengaruh jenis rimpang dan komposisi media tanam terhadap pertumbuhan bibit jahe merah (Zingiber officinale Rosc.). e-Jurnal Agrotekbis. 4(4): 394402.

Basirat Z, Moghadamnia A, Kashifard M, SarifiRazavi A. 2009. The effect of ginger biscuit on nausea and vomiting in early pregnancy. Acta Medica Iranica. 47(1): 51-56.

Chabib R, Rizki MI, Aprianto, Zahrah AM. 2014. Pengembangan formulasi dan evaluasi gummy candies parasetamol untuk anakanak. Jurnal Pharmascience. 1(1): 18-22.

Daulay AS. 2017. Usaha Produk Minuman Kesehatan Jahe Merah Instan Di Kelurahan Binjai Kecamatan Medan Denai. Amaliyah Jurnal Pengabdian Kepada Masyarakat. 1(1): 1-5. https://doi.org/10.32696/ajpkm.v1i1.7

Fauzan S, Rahmadani DF, Aulia W, Devi LS, Akyun Q. 2020. Optimalisasi Potensi Desa Seketi Melalui Inovasi Pembuatan Pie Susu Jahe. Suluh : Jurnal Abdimas. 2(1): 52-59. https:// doi.org/10.35814/suluh.v2i1.1557

Firdaus F, Kresnanto VA, Fajriyanto. 2013. Formulasi nutrasetikal sediaan gummy candies sari buah markisa kuning dengan variasi kadar sukrosa sebagai bahan pemanis. Jurnal Gamma. 8(2): 31-45.

Hartono H, Hutomo K, Mayangsari M. 2012. Pengaruh strategi pemasaran terhadap peningkatan penjualan pada perusahaan dengan menetapkan alumni dan mahasiswa Universitas Bina Nusantara sebagai objek penelitian. Binus Business Review. 3(2): 882897. https://doi.org/10.21512/bbr.v3i2.1271

Iswati S, Purwanto DA, Iswajuni. 2017. Pengembangan produk jahe merah instan dengan technology spray drying di Kabupaten Banyuwangi untuk kualitas ekspor. Jurnal Layanan Masyarakat Universitas Airlangga. 1(2): 83-88. https://doi.org/10.20473/jlm. v1i2.2017.83-88
Jadhav AV, Mohite SK. 2014. A comprehensive review on: medicated chewing gum. Journal of Current Pharma Research. 4(3): 1215-1224. https://doi.org/10.33786/JCPR.2014.v04i03. 006

Juliantoni Y, Wirasisya DG, Hasina R. 2018. Formulasi nutrasetikal sediaan gummy candies sari buah duwet (Syzygium cumini). Jurnal Kedokteran Unram. 7(2): 9-11

Kurniadi D. 2007. Kajian Mandiri Pelatihan dan Pengembangan SDM. Book Report : Universitas Pendidikan Indonesia, Bandung.

Meltzer DI. 2000. Selections from current literature complementary therapies for nausea and vomiting in early pregnancy. Family Practices. 17(6): 570-573. https:// doi.org/10.1093/fampra/17.6.570

Pemerintah Desa Senggigi. 2018. Profil desa Senggigi, www.senggigi.desa.id diakses tanggal 30 Januari 2019.

Sambodo H, Pudjianto H, Whindani K. 2017. Pengembangan potensi ekonomi sumber daya tanaman herbal di kabupaten Banyumas sebagai bahan baku obat. Jurnal Lembaga Penelitian dan Pengabdian kepada Masyarakat Universitas Jendral Soedirman Purwokerto.7(1): 1337-1348.

Triyono K, Sumarmi. 2018. Budidaya tanaman jahe di desa Plesungan kecamatan Gondangrejo kabupaten Karanganyar provinsi Jawa Tengah. Adiwidya. 2(2)

Vutyavanich T, Kraisarin T, Ruangsri R. 2001. Ginger for nausea and vomiting in pregnancy: randomized, double-masked, placebo controlled trial. Obstetrics \& Gynecology. 97(4): 577-582. https://doi.org/10.1097/ 00006250-200104000-00017

Waridin. 2007. Analisis keefisienan usaha tani jahe (studi kasus di Kecamatan Ampel, Boyolali). Jurnal Pembangunan Pedesaan. 7(1): 20-25. 